\title{
AZ EGYETEMI RANGSOROKTÓL A METEOROLÓGIAI KUTATÁS EREDMÉNYESSÉGÉN ÁT A TDK FONTOSSÁGÁIG
}

\author{
Weidinger Tamás \\ ELTE Meteorológiai Tanszék, 1117 Budapest Pázmány Péter sétány 1/A \\ e-mail: weidi@caesar.elte.hu
}

\section{Bevezetés}

Publish or Perish! ...?

A meteorológus MSc kutatószak. Célunk olyan általános alapokat adni, amelyek alkalmassá teszik hallgatóinkat mind a kutatómunkára, mind a meteorológus pálya gyakorlati feladatainak megoldására. Fontos tudni diákjainknak is a hazai egyetemek - $\mathrm{s}$ benne az ELTE - helyét a világban. Elsőként az egyetemi rangsorokkal foglalkozunk, majd a hazai meteorológiai kutatásokat elemezzük a számok tükrében, a Magyar Tudományos Müvek Tára (MTMT mtmt.hu) adatbázisa alapján. (A kutatói pálya nem esik messze a ma oly sokat emlegetett versenyszférától, itt is mérik és jutalmazzák az eredményességet, még ha sokszor formálisan, a számok tükrében.) Végezetül a meteorológus TDK munkája, az elmúlt két év eredményei kerülnek sorra.

\section{Egyetemi rangsorok}

Az egyetemi rangsorok készítése és elemzése egyre divatosabbá vált az utóbbi években. Az ELTE-n külön kutatócsoport foglalkozik a témával: elsősorban a rangsorok társadalmi, kommunikációs hátterét vizsgálják, amihez többek között filozófiai, szociológiai, management és kommunikációelméleti megközelítéseket alkalmaznak (ranking.elte.hu/).

Az egyetemi rangsorok készítésénél több mutatószámot használnak. A legrégebbi, 2003 óta készülő ún. Shanghai listán (ARWU - Academic Ranking of World Universities, shanghairanking.com) a következő mutatószámok szerepelnek (Braun, 2010):

- az egyetem volt Nobel- és Field-díjas hallgatói (súly: 10\%),

- Nobel- és Field-díjas egyetemi oktatók (20\%),

- az „erősen idézett” kutatók száma (21 tudományterületen) (20\%),

- A Nature-ben és Science-ben publikált cikkek száma (a társadalomtudományokban természetesen más mutatók szerepelnek) (20\%),

- a Science Citation Index, az Expanded Social Science Index és az Arts and Humanities Citation Indexben a tárgyévben publikált cikkek száma (20\%),

- az egyetem mérete: az előbbi 5 mutatószám adatai osztva a teljes idejü egyetemi személyzet számával (súly: 10\%).

Más rangsorok ettől eltérő mutatószámokat, illetve súlyokat alkalmaznak. Szerepelhet többek között a vendégoktatók és kutatók száma, az egyetemek szubjektív megítélése és ismertsége (egyes rangsorkészitök az egyetemi oktatók véleményét is kikérik). Ma már nemzetközi megállapodások adnak keretet a rangsorkészítésnek, megszabva az átláthatóság és a minőségbiztosítás elveit (Braun, 2010; Csomós, 2014; Mester, 2018). Ez fontos, hiszen ,jobb híján”, „ha kritizálva és kétkedve is”, de a középiskolás jelentkezőktől az egyetemi polgárokon át a döntéshozókig mind figyelemmel kísérik a rangsorokat, elemzik a változásokat, s hangsúlyozzák a „számukra fontos" tényeket. Vannak olyan web-es oldalak, ahol az aktuális rangsorok mellett megnézhetjük az időbeli változásokat, összehasonlíthatunk egyetemeket, szakterületeket; naprakészen elemezhetjük a rangsorolási szempontokat. Vizsgálatunkat az univer- 
sityrankings.ch svájci internetes oldal adatai alapján végeztük. Négy egyetemi rangsort elemeztünk. Ezek a már említett Shanghai lista, amit a Shanghai Jiao Tong University készít (shanghairanking.com). A következő a brit Times Higher Education (The World University Rankings, timeshighereducation.com), röviden Times, ami egyben üzleti vállalkozás is. Az általuk készített rangsorban 30\%-os súlyt képez az oktatás, aminek a fele a publikációs tevékenység. A harmadik, a szintén brit QS lista (Quacquarelli Symonds, qs.com), ami nyolc méröszámot ötvöz. (Az oktatás egy a nyolc közül.) E mögött is egy üzleti vállalkozás áll: cél a felsőoktatási piac. A negyedik, a Leideni rangsor, amit a Leideni Egyetem készít (CWTS - Centrum voor Wetenschap en Technologische Studies, leidenranking.com). Itt nagy súllyal szerepel a különböző adatbázisokból kinyerhető publikációk, hivatkozások száma és minősége, illetve a tudományos tevékenység és kapcsolatrendszer. A rangsorok és az egyes évek eredményei között is jelentős eltérések lehetnek. Viszont, ha együtt nézzük a rangsorokat, $\mathrm{s}$ követjük az időbeli változásokat már pontosabb képet alkothatunk térségünkről és a felsőoktatásban zajló folyamatokról.

Induljunk el a 2003-as évtöl! Ez volt a Shanghai lista első éve. Az 500-as rangsorában két magyar egyetem szerepelt: a Nobel-díjas Szent-Györgyi Albert professzort (1893-1986) magáénak tudó Szegedi Tudományegyetem (SZTE) az elökelő 201-250. helyen és az Eötvös Loránd Tudományegyetem (ELTE) a 401-450. helyen. Ekkor még kevesebb egyetemet rangsoroltak, illetve a hazai oktatás jó híre, eredményei együtt alakíthatták ki a kiváló induló pozíciót. Nézzük, hogyan változott ez az ELTE példáján!

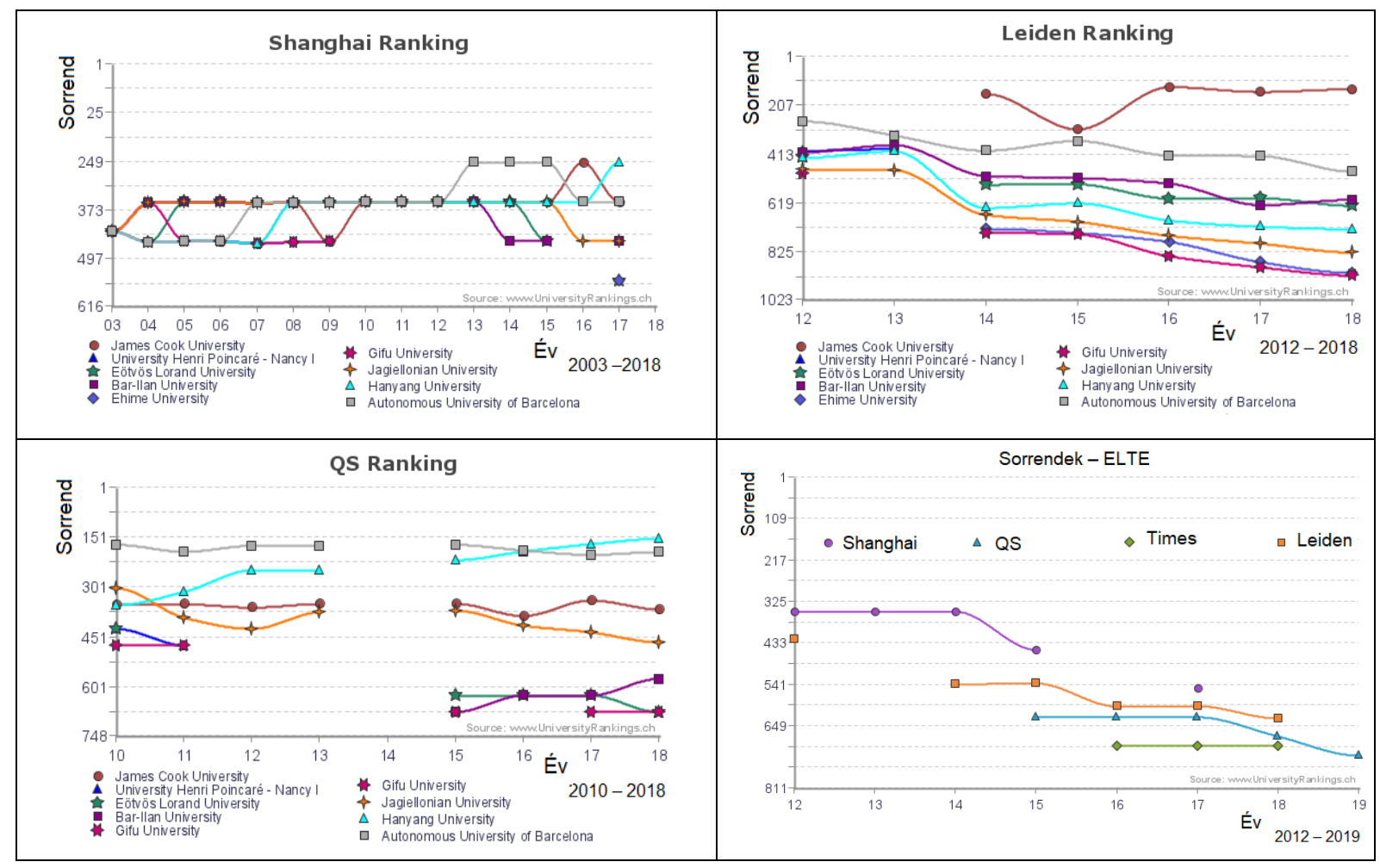

1. ábra: Az ELTE és a vele egy csoportban levő, az ABC szerint legközelebb eső 8 egyetem helyezési sorrendjének változása 2003-tól 2018-ig a Shanghai, a Leiden és a QS rangsor szerint, illetve az ELTE helyezési számának változása a négy egyetemi rangsorban.

Az 1. ábrán kilenc együtt induló egyetem, köztük az ELTE helyezési számának a változását elemezzük. 2003-ban mind ugyanabban a kategóriában (401-450.) voltak. Az intézményeket ABC szerint választottuk ki: ezek voltak „legközelebb” az ELTE-hez. Általában elmondható, hogy nőtt a távolság az együtt indulók között. Többségben vannak a növekvő helyezési szá- 
mok. Különösen a Leiden rangsor szerint kerültek hátrébb a vizsgált egyetemek. Ez utóbbi rangsorban csak az ausztrál James Cook Egyetemnél látunk csökkenő (egyre jobb) helyezési számot. A Shanghai és a QS rangsorban egy európai (Autonomous University of Barcelona) és egy távol-keleti (Hanyang University, Dél-Korea) egyetem kapott a kezdetinél jobb helyezést. Az ELTE a széthúzódó mezőny alsó felében van a Shanghai és a QS rangsor szerint, míg a Leiden rangsor felső középmezőnyében helyezkedik el a 9 egyetemet tekintve. Nincs okunk szomorkodni, de különösebben örülni sem. A mezőny e részében a csökkenö helyezési számok a jellemzőek. Végezetül nézzük az ELTE helyét a négy rangsorban (1.ábra, jobb alsó panel)! Itt is növekvő helyezési számokat látunk. Jó hír, hogy az elmúlt 2-3 évben már nem, vagy csak alig változik (alig romlik) a pozíciónk.

Hogy alakul a többi hazai egyetem helyzete a négy rangsorban? Erre a kérdésre ad választ a 2. ábra. A legjobb ezer egyetem között (a különböző rangsorok jellegénél fogva is) eltérö számban találunk hazai egyetemeket, összesen nyolcat. Az ELTE, a Budapesti Müszaki és Gazdaságtudományi Egyetem (BME) és a SZTE mind a négy rangsorban szerepel. A csökkenő trend (nagyobb helyezési szám) különösen a Leiden rangsorban szembetünő (itt kiemelkedően fontos a publikációs tevékenység). Jó hír, hogy a QS és a Times rangsorban az utóbbi években már nem figyelhetünk meg csökkenő trendet, sőt a Times rangsorban a Semmelweis Egyetem (SOTE) kis mértékben, de elöre lépett. A hazai egyetemek közül, a rangsoroktól függően, az ELTE, a SOTE és az SZTE van elöl. A helyezések évről évre változnak (természetes fluktuáció), így vigyázni kell a kijelentésekkel. (Volt olyan év, amikor pl. a Középeurópai Egyetem a Times rangsor élén szerepelt a hazaiak között, DE a másik rangsorolt két évben már csak a középmezönyben.)

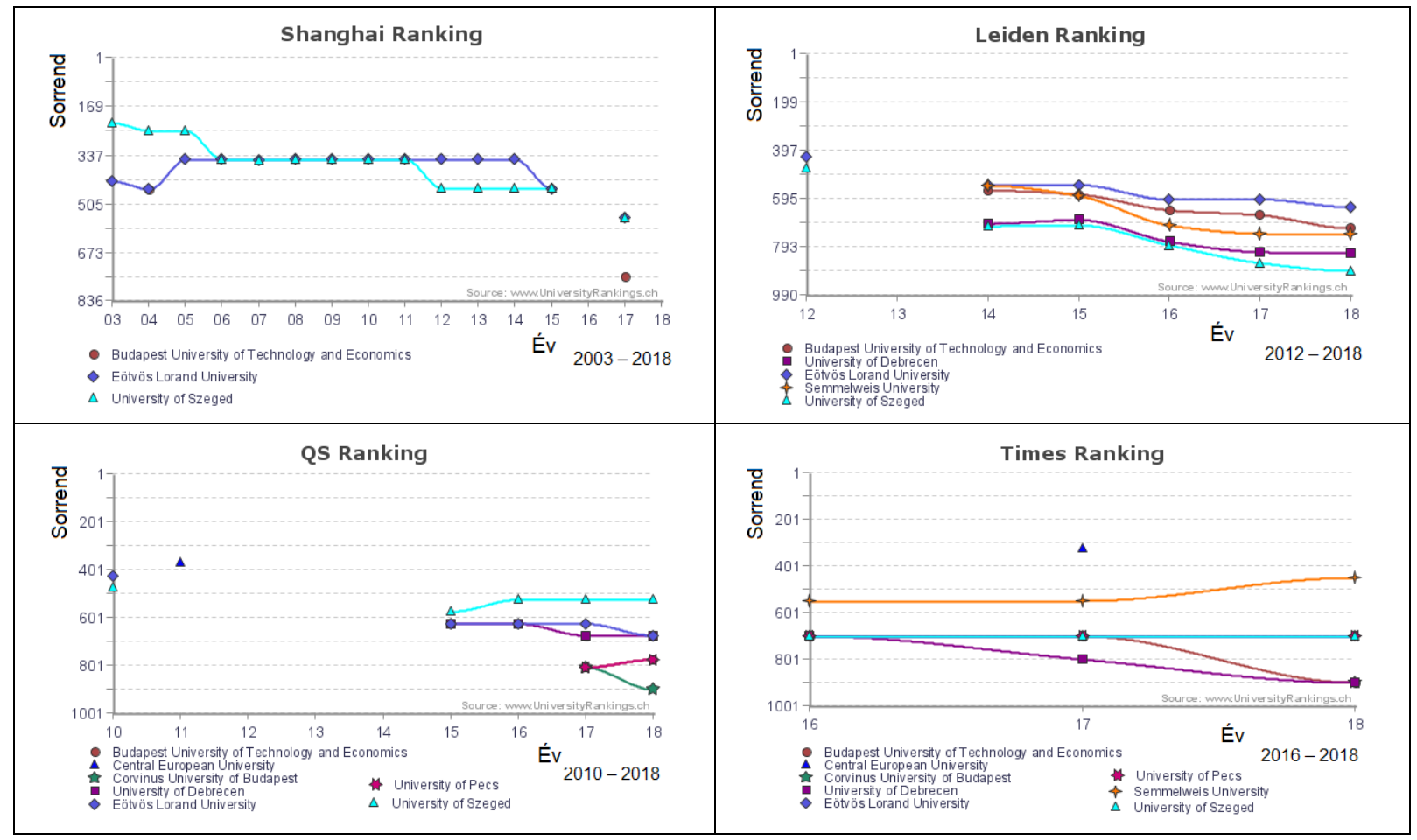

2. ábra: Magyarországi egyetemek helye a különböző egyetemi rangsorokban (2003-2018).

Nézzük meg, hogyan szerepel az ELTE a régiós összehasonlításban! Két osztrák (Bécsi és a Grazi Egyetem), illetve a régiós (Csehország, Szlovákia Szlovénia, Horvátország, Szerbia, Románia) fővárosi tudományegyetemeket és a hozzánk közel eső krakkói Jagelló Egyetemet hasonlítottuk össze a Shanghai és Leiden rangsor alapján (3. ábra). Az élen a két ausztriai egyetem áll, de említhetnénk Ausztriából más egyetemet is, például az innsbruckit, vagy a 
bécsi agráregyetemet $\left(\mathrm{BOKU}^{1}\right)$. A Shanghai listán elöl találjuk a prágai Károly Egyetemet is. Itt sajnos a leszakadók között vagyunk, míg a Leiden listán a Ljubljanai Egyetemmel együtt a 3-4. helyen. Az osztrák egyetemeken kívül, amelyek tartják a pozíciójukat a többiek hátrébb kerültek a Leiden rangsorban. Jó hír, hogy az elmúlt években pozíciónk stabilizálódni látszik: mindez az 500-1000. közötti helyen. Van hova fejlődni, akár csak a 6 évvel ezelötti szintre. Gyors változásra (javulásra) jelentősebb ráfordítások nélkül (anyagi és humán erőforrások) ne számítsunk. Ez ellentmond a gazdaság törvényszerüségeinek.

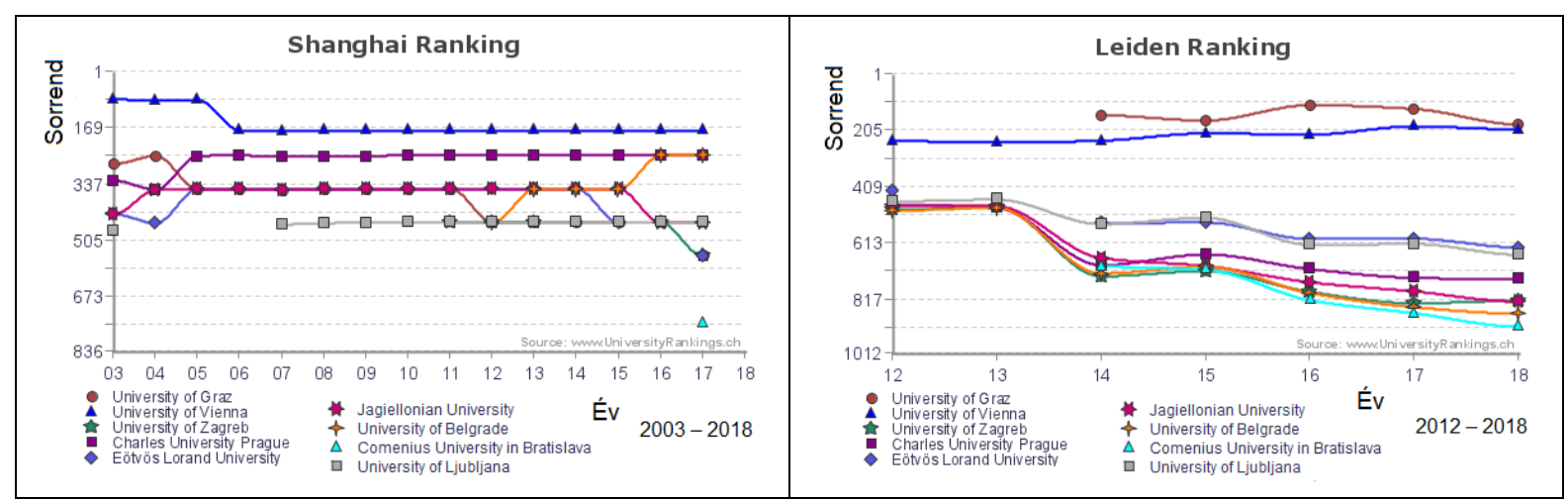

3. ábra: Kilenc régióbeli egyetem helye a Shanghai és a Leiden rangsorban (2003-2018).

Végezetül nézzünk körül saját házunk táján! A Shanghai listán tudományterületek szerinti rangsorok is vannak. Itt 2018-ban az ELTE a matematika szakterületen szerepelt a legjobban (151-200.), de ott van a fizika (201-300.), az ökológia (301-400.) és a földtudomány (401500.) listáján is.

Mi a helyzet a légkörtudományokkal? Ilyen sorrend is van. Itt az első a Colorado Egyetem (USA, Boulder), míg az ELTE a 301-400. helyen áll. Ez örömteli! Régiónkból ebben a kategóriában van a Zágrábi és a Belgrádi Egyetem, míg a prágai Károly Egyetem, a brnoi Masaryk Egyetem, a Ljubljanai Egyetem és a krakkói Jagelló Egyetem elörébb foglal helyet (201-300.). A legelőkelőbb hely (51-75.) az Innsbrucki Egyetemé. A Bécsi Egyetem a 101150. helyen áll; ők a képzeletbeli dobogó második helyezettjei a régióban.

\section{A hazai meteorológiai kutatás a publikációk tükrében}

A meteorológiában együtt van jelen az alap- és alkalmazott kutatás, illetve a szolgáltatás: legyen az viharjelzés, repülés- vagy katonai meteorológia. Fontos az alaprendszerek fenntartása, és fejlesztése is a mérésektől az informatikai rendszeren át egészen a tájékoztatási feladatokig. Ez a sokszínűség egyrészt sok előnyt, feladatot és lehetőséget jelent, másrészt a közszférában és a versenyszférában dolgozóknál nem jut (nem juthat) elég idő kutatásra és publikálásra. Az oly fontos belső innovációk, módszerfejlesztések nem mindig érnek cikkekké (persze ott nem is ez a fó cél).

Magyarországon az egyik legelfogadottabb intézmény/köztestület a Magyar Tudományos Akadémia (MTA). A köztestületnek tudományos fokozattal ( $\mathrm{PhD}$, kandidátus, a Tudomány(ok), illetve az MTA Doktora) rendelkezők lehetnek a tagjai. Az Akadémiának 11 osztálya van, köztük a X. Földtudományok Osztálya. Ennek része az MTA Meteorológiai Tudományos Bizottsága (MTA MTB), ami a hazai meteorológiai kutatást reprezentálja. Vezetője

\footnotetext{
${ }^{1}$ BOKU - Universität für Bodenkultur Wien. A BOKU a XIX. század második felében, a Kiegyezés után alakult az akkori Magyaróvári Gazdasági Akadémia professzori karából. (Hol van most a rangsorokban az anyaintézmény?) A Magyaróvári Gazdasági Akadémiáról lásd pl. Kölcsei Ferenc cikkét 1837-ből, mek.oszk.hu/00000/00058/html/kolcsey.htm)
} 
Bartholy Judit (az MTA doktora, ELTE Meteorológiai Tanszék), titkára Lakatos Mónika (PhD, OMSZ) a 2017-2020-as akadémiai ciklusban. A munka 5 Albizottságban folyik (mtb.met.hu).

Az MTA köztestületének több mint 15000 tagja van, ezek közül 86-an tartoznak a Meteorológiai Tudományos Bizottsághoz. Közülük 5 akadémikus, 13 a Tudomány(ok), illetve az MTA doktora, 24 kandidátus, 44 pedig $\mathrm{PhD}$ fokozattal rendelkezik. Nem minden tudományos fokozattal rendelkező, s meteorológiai témával foglalkozó kutató tagja a köztestületnek, s természetesen tudományos fokozat nélkül is lehet jó cikket írni, DE ez a 86 fó mégis jól reprezentálja a hazai meteorológiai kutatást. Elsőként nézzük a korösszetételt (4. ábra)! Harminc év alatti tagja nincs az MTA MTB-nek, hiszen idő kell a PhD fokozat megszerzéséhez. A tízévenkénti korfa jó közelítéssel egyenletes eloszlást mutat (legtöbben az 50-60 és a 60-70 éves korosztályban vannak). Tanulságos a munkahely/tevékenység szerinti megoszlás is. A kördiagramról leolvasható, hogy a minősített kutatók több mint $40 \%$-a az egyetemi szférában dolgozik. Második helyen az OMSZ szerepel (15\%). Ez erösen csökkenő részarány. 10\% felett van a külföldön dolgozók száma is (egy kisebb évfolyam). A tagok több mint negyede nyugdíjas (ez a második legnagyobb csoport.)

A meteorológiai kutatásban a hangsúly ma már az egyetemeken van. Ez fokozatosan alakult ki. Az 1990-es évekig az OMSZ volt a meghatározó. Az új helyzethez való alkalmazkodás fontos eleme lehetne az egyetemek fokozott bevonása az alkalmazott kutatásokba, szerződéses együttmüködésekbe, ami kapacitásbővítést, a fiatal kutatói gárda alkalmazását és megtartását is jelenthetné. (Nincs meteorológiával foglalkozó kutatóintézet, s csupán egy MTA Levegökémiai Kutatócsoport müködik Veszprémben a Pannon Egyetemen.) A szaktudás megvan! Összhangba hozható a gyakorlati feladatok megoldását célzó kutatás és az ehhez kapcsolódó, ezt lezáró publikációs tevékenység, ami az egyetem lényegéből fakad.

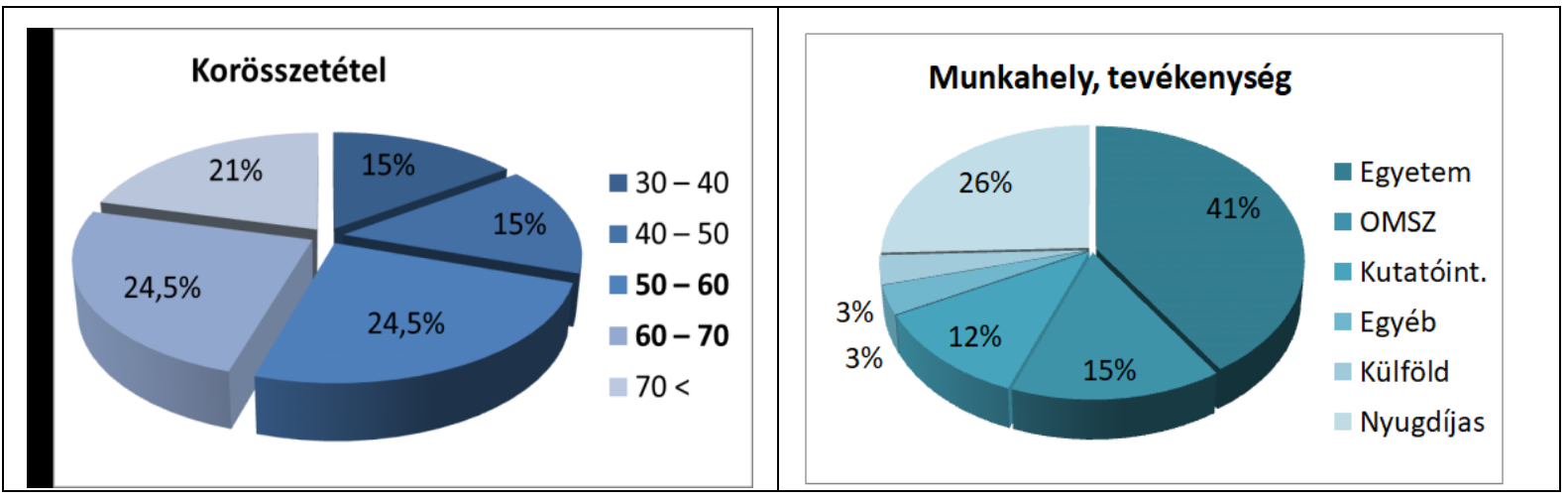

4. ábra: Az MTA Meteorológiai Tudományos Bizottsághoz jelentkezett 86 köztestületi tag életkor és munkahely/tevékenység szerinti megoszlása.

Kutatási témákat tekintve a levegökémiában és klimatológiában születik a legtöbb publikáció. Találunk elméleti meteorológiával, numerikus modellezéssel, felszín-légkör kölcsönhatásokkal és agrometeorológiával foglalkozó cikkeket is. Szintén alul reprezentáltak a szinoptikus meteorológiával kapcsolatos témák. Vannak egyes kutatókhoz köthető kiváló cikkek, tudományos iskolák, mint Pécsen a felhőfizika, Siófokon a mezometeorológia, vagy Keszthelyen az agrometeorológia. E tudományterületek ( $D E$ a légkördinamika is) - még ha a folyóiratok legjobb 10\%-ában (D1), vagy a felső 25\%-ában (Q1) publikálják is az eredményeket, természetüknél fogva csak kevés hivatkozással rendelkeznek. Természetesen itt is vannak kivételek, mint a külföldön dolgozó Horváth F. Ákos (Németország), Szunyogh István (USA) vagy Tóth Zoltán (USA) cikkei. (Nem mindegyikük tagja az MTA köztestületének, illetve nem mindegyikük szerepel az MTMT adatbázisában.) 
A hazai publikációs tevékenység (cikkek, könyvek, konferencia összefoglalók, elöadások, $s t b$.) és a publikációkra adott hivatkozások legnagyobb adatbázisa a Magyar Tudományos Művek Tára (MTMT, mtmt.hu). Ezt használják a tudományos tevékenység megítélésénél ( $p l$. kutatási pályázatok, PhD és az MTA doktora fokozat megszerzéséhez szükséges tudományos közlemények elismertetése, egyetemi és akadémiai kutatói előmeneteli és minősitési rendszer), de ezt kérik a Kar Kiváló Hallgatója, vagy a Nemzeti Kiválósági Ösztöndíj beadásánál is. (Javasoljuk az MTMT-be történő regisztrációt, minden publikációval rendelkező hallgatónak!) Az adatbázis frissítésére, karbantartására nagy figyelmet fordítanak, különösen az akadémiai és az egyetemi szférában. Az ELTE-n például évente kétszer kell aktualizálni a publikációkat és a hivatkozásokat. Ezt el is várják, de a szükséges segítséget is megadják.

A publikációs tevékenység felértékelődése, a publikációk számának dinamikus növekedése az elmúlt negyedszázad eredménye. Ennek természetes következménye a hivatkozások (már ha fontos a téma és jó a cikk) számának növekedése. Ez egyrészt jó, hiszen mérhetővé teszi a tudományos tevékenységet, ami erős ösztönző hatással bír, ugyanakkor rossz, mert hátrányba kerülnek az alkalmazott területek, ahol az eredményességet nem csupán a cikkek jelzik. Ez igaz az OMSZ-nál folyó munkára is.

1. táblázat: Az MTA MTB tagjainak publikációs mutatói az MTMT (mtmt.hu) adatai alapján az oda felvitt hazai és külföldi lektorált cikkek és az összes független hivatkozás alapján a 30-70 év közötti korosztályban.

\begin{tabular}{|l|c|l|l|l|l|l|l|}
\hline Életkor [év] & MTMT-ben & \multicolumn{3}{|c|}{ Cikkek } & \multicolumn{3}{c|}{ Független hivatkozások } \\
\cline { 3 - 8 } & szerepel [\%] & Átlag & Min. & Max. & Átlag & Min & Max \\
\hline $30-40$ & 100 & 16,5 & 2 & 41 & 131 & 7 & 507 \\
\hline $40-50$ & 85 & 32,0 & 3 & 90 & 269 & 0 & 933 \\
\hline $50-60$ & 67 & 48,0 & 6 & 113 & 1269 & 36 & $\mathbf{4 9 2 0}$ \\
\hline $60-70$ & 71 & 77,5 & 12 & 133 & 751 & 41 & 2311 \\
\hline \multicolumn{7}{|c|}{} & \multicolumn{6}{c|}{ 2018. augusztusi adatok alapján } \\
\hline
\end{tabular}

Nézzük a meteorológiai kutatást az MTMT tükrében! Az MTA MTB 30-70 év közötti tagjainak kutatási tevékenyégét elemezzük. A 70 év felettieknél ez az adatbázis már nem ad összehasonlítható képet. Korábban más publikációs szokások voltak. Megjegyezzük, hogy a köztestületi tagok közül nem mindenki szerepel az adatbázisban, s nem is mindenki frissíti rendszeresen az adatait. Az 1. táblázatban tízévenkénti bontásban mutatjuk be az egyes korosztályok tudományos tevékenységét. Az évek növekedésével természetesen nő a lektorált (magyar és idegen nyelvü, alapvetően angol) cikkek száma. Szintén nőnek a független hivatkozások. (Független hivatkozás alatt azt értjük, hogy nincs közös szerzöje a hivatkozó és a meghivatkozott publikációnak.) A tudományos aktivitásnak csak egy részét fedik le a cikkek. Gondoljunk csak a könyvekre, könyvfejezetekre, disszertációkra, konferencia összefoglalókra! Vizsgálatunkban az összes (nemcsak a lektorált folyóiratokban elöforduló) független hivatkozást figyelembe vettük az MTMT-böl.

A PhD fokozat megszerzésének is feltétele az MTMT adatbázis megléte. E nélkül nem lehet senki az MTA köztestületének tagja sem. Így természetes, hogy a 30-40 év közöttiek mindegyikének van MTMT azonosítója. Ez nem mondható el az idősebb korosztályokról. A legrosszabb a helyzet az 50-60 évesek között, ahol ez az arány mindössze $67 \%$.

Az átlagos cikktermés (ennyi cikkben vesznek részt) a 30-40 éves korosztályban 16,5, míg a 60-70 éveseknél 77,5. Egy-egy cikk általában több szerző munkája. Nagy az eltérés a legtöbbet publikálók és a legkevesebb cikkben résztvevők között is. Ez természetes, hiszen a tudományos fokozat megszerzése után nem mindenki választja a kutatói életpályát, illetve az egyetemi és akadémiai szférán kívül az eredményességnek nem egyedüli fokméröje a publikáció. A hivatkozások helyett ott van a gazdasági haszon, a piacképes, eladható tudás, az 
innováció vagy a $\mathrm{K}+\mathrm{F}$ tevékenység. Gondoljunk csak a veszélyjelzésre, az országos Jégkármérséklő rendszerre, a meteorológiai mérőrendszer megújítására, a numerikus módszerfejlesztésekre, vagy az újgenerációs Hawk meteorológiai munkaállomásra. Persze e két dolog (fejlesztés és publikáció) jó esetben együtt is járhat.

Legtöbb publikációja (133) Makra László professzor úrnak van (SZTE Mezőgazdasági Kar). Ö statisztikus éghajlattannal foglalkozik. Független hivatkozásainak száma meghaladja a 2300-at. A másik három korcsoportban az ELTE Meteorológiai Tanszékröl került ki a legtöbbet publikáló kutató (Breuer Hajnalka, Pongrácz Rita és a cikk szerzője). De nézzük, mire elég a sok cikk!

Mi a helyzet a független hivatkozásokkal? Legtöbb hivatkozással az 50-60 éves korosztály rendelkezik. Ök már belenőttek az új tudományos értékelési rendszerbe, a cikkírás fontosságába, s számos nemzetközi (európai és tengerentúli) kutatási programban vehettek részt, ami az előttük járók kapcsolatteremtő erejét dicséri. Ebből a szempontból a 30-as, 40-es generációnak is jó lehetőségei vannak. Természetessé vált a nemzetközi együttmüködés. A 30-40 éves korosztályban egyébként a legtöbb független hivatkozást (507) Gál Tamás a SZTE Éghajlattani és Tájföldrajzi Tanszékének egyetemi docense kapta. Az ő területe a városklímakutatás.

A magyar meteorológia sikerágazata a levegőkémia. E tudományterület a nemzetközi meteorológiai szakirodalom több mint 20\%-át képviseli. Máig hat Mészáros Ernő akadémikus (OMSZ, majd a 90-es évektől a Pannon Egyetem) iskolateremtő tevékenysége. A legtöbb független hivatkozása (4920) Gelencsér Andrásnak van. Ö a Pannon Egyetem Levegőkémiai Kutatócsoportjának a vezetője, az egyetem rektora. Vele együtt összesen tizenhárman vannak 1000 független hivatkozás felett: közülük még négyen az MTA Levegőkémiai Kutatócsoportjához kötődnek (Hoffer András, Kiss Gyula Molnár Ágnes és a korábban ott dolgozott Krivácsy Zoltán). Két, az OMSZ-ból nemrég nyugdíjba ment levegőkémikus (Horváth László és Haszpra László) is 1000 feletti független hivatkozással rendelkezik. Szegedről ketten: Unger János és Makra László, az egri egyetemről pedig Mika János klimatológus tagja a „klubnak”. Egy USA-ban dolgozó kutató Csiszár Iván mindössze 6 cikket töltött fel az MTMT-be, de ezekre 1095 hivatkozást kapott. Mi lehet a többi cikkel?

Az ELTE Meteorológiai Tanszéken Bartholy Juditnak és a cikk szerzőjének van 1000 feletti hivatkozása. Barcza Zoltánnak és Pongrácz Ritának pedig már 900 feletti az idézettsége. Ez a publikációs tevékenység, kiegészülve más tanszékeken folyó hasonló kutatásokkal ahogy az előző részben már említettük - a légkör-tudományokban a 301-400. helyre elég az ELTE-nek. Mindez az oktatási és tudományszervezési feladatok mellett történik. A továbblépéshez, a pozíciók megerösitéshez további eröforrások kellenek.

A meteorológus MSc kutatószak. Így mind a hallgatók, mind a Tanszék érdeke, hogy minél hamarabb bevonjuk hallgatóinkat a kutatómunkába. Ennek egyik eszköze a tudományos diákköri tevékenység. A cikk következő részében ezzel foglalkozunk.

\section{Diákkutatás, TDK-tevékenység}

Az oktatás és a kutatás színvonalának alapja a tanulni akaró, motivált hallgató és a megfelelő számú és tudású (tudományos fokozattal rendelkező, nemzetközileg ismert) oktató. Nézzük a hallgatói és az oktatói létszám változásait az 1930-as évek végétől napjainkig (2. táblázat)! A hallgató-oktató arány az 1937/38-as tanévtől egészen a rendszerváltozásig (1990/91) 6,2 és 8,2 között ingadozott. Ezután indult a felsőoktatás tömegesítése, ami megfelel a kor követelményeinek. A hallgatói létszám az 1990/91-es 102 ezerről 380 ezer fö fölé nőtt a 2005/06-os tanévre. Az oktató-hallgató arány 6,2-ről 16,4-re emelkedett. Ez az arányszám megmaradt 2012/13-ban is, bár csökkenő (338 ezer) hallgatói létszám mellett. A csökkenő létszámú évfolyamok (hány gyermek születik egy évben) természetes következménye - még a növekvő 
$\mathrm{PhD}$ és szakképzés ellenére is - a fogyó hallgatói létszám. A Központi Statisztikai Hivatal (KSH, ksh.hu/docs/hun/xstadat/xstadat_eves/i_zoi007a.html) szerint a 2017/18-as tanévben már csak 283 ezer hallgató iratkozott be a 64 felsőoktatási intézmény valamelyikébe. A jó hír, hogy fokozatosan javul a hallgató-oktató arány (jelenleg 12,3), s az utóbbi 5 évben ismét nőtt az oktatói létszám, bár még nem érte el a Bokros-csomag előtti, 2006-os számot (23 188). Ahogy a meteorológiai kutatási potenciál intézmények közötti megoszlásából láttuk, úgy más területeken is nő az egyetemek szerepe. Ha meg akarjuk tartani, illetve növelni az egyetemek színvonalát, $\mathrm{s}$ fejleszteni a kutatási és az innovációs potenciált, mindenképpen javítani kell a hallgató-oktató arányt.

Nézzük meg, hogyan változott a TDK tevékenység e felsőoktatási környezetben! A csökkenő hallgatói létszám néhány éves késéssel az OTDK (Országos Tudományos Diákköri Konferencia) résztvevők számában is megjelenik (2. táblázat). A legutóbbi 2017-es XXXIII. OTDK 16 szekciójában elhangzott több mint 4100 előadással, a mögöttük levő tudományos háttérrel nincs mit szégyenkezni, de ne feledjük el, hogy más országokban is egyre aktívabb a hallgatói tudományos élet (Weidinger, 2014).

2. táblázat: A hallgatói és oktatói létszám, a hallgató/oktató arány, valamint a diákköri dolgozatok számának alakulása a hazai felsőoktatásban 1937-től 2018-ig.

(Források: ELTE Tehetséggondozási koncepció, 2008; Weidinger, 2014, 2016; ksh.hu/docs/hun/xstadat/xstadat_eves/i_zoi007a.html)

\begin{tabular}{|c|r|r|c|c|}
\hline Tanév & Hallgatók & Oktatók & Hallgató/oktató arány & OTDK dolgozatok \\
\hline $1937 / 38$ & 11747 & 1724 & 6,8 & - \\
\hline $1960 / 61$ & 44558 & 5635 & 7,9 & 429 \\
\hline $1970 / 71$ & 80536 & 9791 & 8,2 & 668 \\
\hline $1980 / 81$ & 101166 & 13890 & 7,3 & 2388 \\
\hline $1985 / 86$ & 99344 & 14850 & 6,7 & 2151 \\
\hline $1990 / 91$ & 108376 & 17302 & 6,2 & 1620 \\
\hline $1995 / 96$ & 195586 & 18098 & 9,9 & 2383 \\
\hline $2000 / 01$ & 327289 & 22873 & 12,9 & 3143 \\
\hline $2005 / 06$ & 380632 & 23188 & 16,4 & 4612 \\
\hline $2012 / 13$ & 338467 & 20555 & 16,4 & 4603 \\
\hline $2014 / 15$ & 306524 & 21080 & 14,5 & 4111 \\
\hline $2016 / 17$ & 287018 & 22436 & 12,8 & $*$ \\
\hline $2017 / 18$ & 283380 & 23110 & 12,3 & \\
\hline \multicolumn{5}{|c|}{ * Az OTDK-t páratlan években rendezik. Az adatok ennek megfelelö évre vonatkoznak. }
\end{tabular}

Az Meteorológiai Tanszék 1945 őszén alakult. Kezdetektől fogva fontosnak tartjuk a hallgatókkal való foglalkozást, a kutatásokba történő bevonásukat, a jó hallgató-oktató viszony kialakítását, amit megkönnyítenek a kis létszámú évfolyamok (Bartholy \& Gyuró, 2012; Weidinger, 2012).

A diplomát szerzett, illetve TDK dolgozatot készítő hallgatók számát az 5. ábrán szemléltetjük 1960-tól máig. A diákköri dolgozatok számáról az 1970-es évek második felétől vannak megbízható adatok. Ekkor Rákóczi Ferenc (1931-2000) volt a diákkör vezetője, majd tőle vette át a tisztet 1984-ben a cikk szerzője. Jól látható kapcsolat van a végzett meteorológus hallgatók és a TDK dolgozatot készítők között. (Egy évnyi időeltolás esetén (a diplomát szerzettek száma egy évvel megelözi a TDK dolgozatot készitök számát) a korreláció-négyzet: $R^{2}=0,41$.). A legtöbb dolgozat 2010-15 között készült, voltak olyan évek, amikor 20 feletti számmal. Ezt követően csökkent a hallgatói létszám, s vele a diákköri dolgozatok száma. Évi 8-10 dolgozattal számolhatunk. Közös érdekünk és felelősségünk (mármint az oktatóknak és 
a hallgatóknak), hogy ez a szám ne csökkenjen. Sokszor említettük, de igaz, hogy a diákköri munka a kutatóvá válás első lépése. Megtanít cikket írni, előadást tartani, megkönnyíti a szakdolgozat, illetve a diplomamunka írását, segíti a pályázatok, külföldi részképzések elnyerését, s nem utolsó sorban növeli a Tanszék kutatási potenciálját.

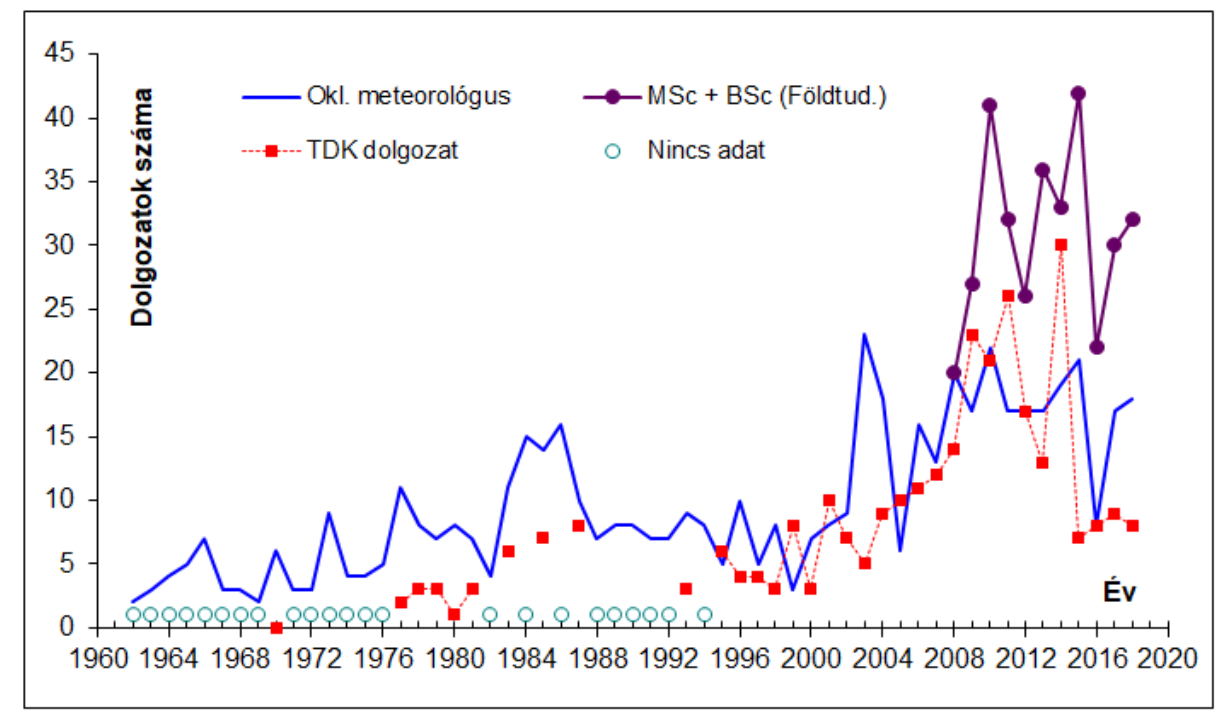

5. ábra: Diplomát szerzett meteorológus hallgatók és az évente készített TDK dolgozatok száma 1960-2018.

Hallgatóink hagyományosan jól szerepelnek a kétévente megrendezésre kerülő OTDK Fizika-Földtudományok-Matematika (FiFöMa) Szekciójában. 2015-ben Kolozsváron, míg 2017-ben Debrecenben rendezték a konferenciát. A köztes években van az Országos Felsöoktatási Környezettudományi Diákkonferencia (OFKD). A legutóbbit 2018 tavaszán az ELTE rendezte. Nézzük a számokat! Hogyan szerepelt az ELTE, a Természettudományi Kar (TTK) és a Meteorológus TDK? A legutóbbi 5 év adatait a 3. táblázat tartalmazza.

3. táblázat: Az OTDK és az OFKD konferenciákon való szereplés főbb adatai az utóbbi 5 évben. (Az OFKD müvészeti szekciójának a résztvevőit a + jel után írtuk.)

\begin{tabular}{|c|c|c|c|c|c|c|}
\hline Konferencia, év & Helyszín & Összes & ELTE & ELTE TTK & \multicolumn{2}{|c|}{$\begin{array}{l}\text { Meteorológus } \\
\text { TDK }^{* *}\end{array}$} \\
\hline OFKD, 2014 & Pécs & $178+6$ & 30 & 30 & 9 & $(2,1,2,2)$ \\
\hline OTDK, 2015 & Kolozsvár $^{+}$ & 4603 & 642 & 291 & 23 & $(2,5,1,4)$ \\
\hline OFKD, 2016 & Szeged & 129 & 23 & 23 & 11 & $(1,1,2,2)$ \\
\hline OTDK, 2017 & Debrecen $^{+}$ & 4111 & 588 & 208 & 10 & $(2,3,1,2)$ \\
\hline OFKD, 2018 & ELTE, Bp. & 124 & 39 & 38 & $11^{*}$ & $(1,3,2,1)$ \\
\hline
\end{tabular}

+ A FiFöMa (Fizika-Földtudományok-Matematika) OTDK Szekció konferencia helyszínei.

* A két külföldi Stipendium Hungaricum ösztöndíjassal együtt.

** A dolgozatok száma után zárójelben az elért 1., 2., 3. díjak, különdíjak és dicséretek.

Az ELTE TTK 12 diákköre közel 300 dolgozattal indult a 2015-ös XXXII. OTDK négy szekciójában. A magas részvétel egyik indoka, a FiFöMa konferencia kolozsvári helyszíne volt. Emlékezetes konferenciát rendeztek. Közel 300 elöadás hangzott el, közöttük 23 a meteorológus TDK-ból. Az eredményességre sem panaszkodhatunk. Tizenketten kaptak díjat, illetve különdíjat, ami a részarányunkhoz képest is kiemelkedö eredmény. 2017-ben Debrecenben 36 szekcióban 275 előadás hangzott el. Itt kevesebben voltunk. A Meteorológus TDK 
11 dolgozattal szerepelt (jól látszik a csökkenő hallgatói létszám hatása). Az eredményességünkre itt sem lehetett panasz. Nyolc díjat, köztük két első és három második helyezést szereztünk. A következő XXXIV. FiFöMa konferencia Egerben lesz az Eszterházy Károly Egyetemen, 2019 tavaszán (április 23-26.). A jelentkezési határidő 2019. január 9. Ide a 2018. decemberi Meteorológus TDK Konferenciáról lehet bejutni.

Hallgatóink jól szerepeltek az elmúlt három OFKD-n is. A konferencián résztvevők számadatai alapján azonban érdemes felhívni a figyelmet néhány változásra. A környezettudományi képzés átalakulása - kevesebb képzőhely és hallgató - visszatükröződik a csökkenő részvételben. Az utóbbi két konferencián elmaradt a mủvészeti szekció - egy színfolttal kevesebb. Az ELTE-ről érkező dolgozatok 30-45\%-át hagyományosan a Meteorológus Diákkör adja, ami önmagáért beszél. A meteorológusok jól felkészültek, kiválóan szerepeltek. Az idei konferencián résztvevő 11 hallgatónk közül heten szereztek díjat, három szekcióban. (Összesen 12 szekcióban versenyeztek a hallgatók.) Új elemként rendezték meg az angol nyelvü Környezettudományi Szekciót a Stipendium Hungaricum ösztöndíjas hallgatóknak. Itt Mészáros Róbert és Leelössy Ádám két tanítványa Abbasi Maria Akhtar és Atfeh Bushra második, illetve harmadik helyezést szerzett (I. díjat nem adtak ki a szekcióban). Kettejük közül Atfeh Bushra az ELTE Meteorológiai Tanszéken folytatja a tanulmányait mint PhD hallgató. Gratulálunk!

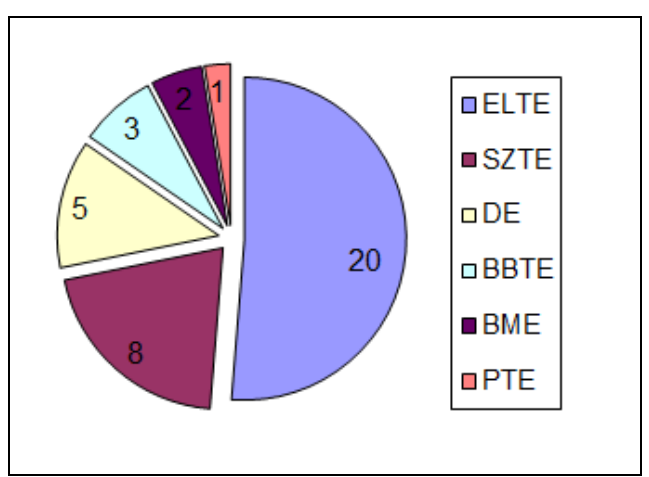

XXXIII. OTDK FiFöMa, Debrecen, 2017

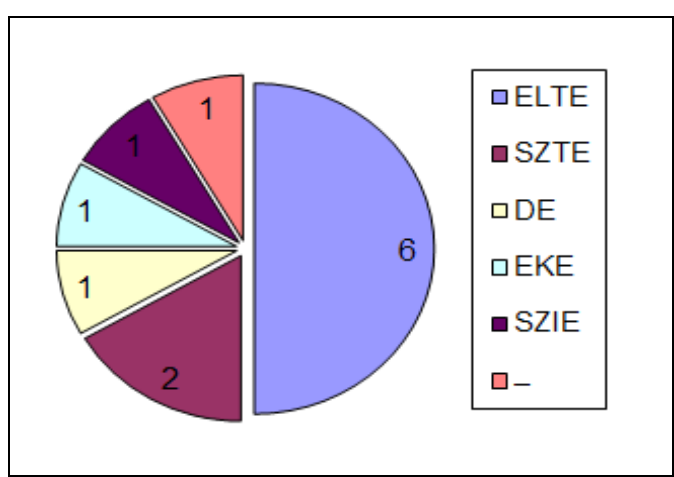

XVI. OFKD, Budapest/ELTE, 2018

6. ábra: Felsőoktatási intézmények az első helyet elért hallgatók tükrében.

ELTE - Eötvös Loránd Tudományegyetem, SZTE - Szegedi Tudományegyetem,

DE - Debreceni Egyetem, BBTE - Babes-Bolyai Tudományegyetem,

EKE - Eszterházy Károly Egyetem, BME - Budapesti Müszaki és Gazdaságtudományi Egyetem, SZIE - Szent István Egyetem, PTE - Pécsi Tudományegyetem

A 2017-es FiFöMa konferencia és az idei OFKD konferencia első helyezettjeinek egyetemek szerinti megoszlását a 6 . ábra szemlélteti. Nőtt az ELTE eredményessége a korábbi évekhez képest. Mi hoztuk el az első díjak felét mindkét konferencián, amihez a meteorológus hallgatók is „tevékenyen” hozzájárultak. Még két olyan egyetem volt, ahonnan mindkét konferencián szereztek első díjat; ezek a Szegedi Tudományegyetem és a Debreceni Egyetem.

Az elmúlt két konferencián első díjat kapott hallgatóinkat, az általuk készített TDK dolgozatok címét és témavezetőiket a 4. táblázatban mutatjuk be. Ezúton is gratulálunk!

Ahogy a korábbi években, úgy most is hangsúlyozzuk: érdemes TDK munkát végezni, folytatni a hagyományokat. Feladat, diákköri téma van böven akár a cikk szerzőjénél, akár más tanszéki kollégánál. A TDK munka, a diákköri előadások növelik a rutint, legyen szó egyetemi vizsgákról, vagy a diplomamunka készítéséröl. Minden évben vannak tehetséges diákjaink a Kar Kiváló Hallgatói között, illetve kapnak Nemzeti Felsőoktatási Ösztöndíjat (5. táblázat). 
4. táblázat: Első díjas hallgatóink az OTDK-n (2017) és az OFKD-n (2018).

\begin{tabular}{|l|l|l|l|}
\hline Konferencia & Hallgató & Témavezető & A TDK dolgozat címe \\
\hline $\begin{array}{l}\text { XXXIII. } \\
\text { OTDK }\end{array}$ & $\begin{array}{l}\text { Balogh } \\
\text { Adrienn Judit }\end{array}$ & Geresdi István & $\begin{array}{l}\text { Hópelyhek olvadásának számítógépes } \\
\text { modellezése }\end{array}$ \\
\hline $\begin{array}{l}\text { XXXIII. } \\
\text { OTDK }\end{array}$ & Dian Csenge & $\begin{array}{l}\text { Pongrácz Rita, } \\
\text { Bartholy Judit, } \\
\text { Dezső Zsuzsanna }\end{array}$ & $\begin{array}{l}\text { A budapesti városi hösziget elemzése a } \\
\text { lokális klímazónák felhasználásával }\end{array}$ \\
\hline $\begin{array}{l}\text { XVI. } \\
\text { OFKD }\end{array}$ & $\begin{array}{l}\text { Kalmár } \\
\text { Tímea }\end{array}$ & $\begin{array}{l}\text { Pieczka Ildikó, } \\
\text { Pongrácz Rita }\end{array}$ & $\begin{array}{l}\text { Finomskálájú regionális klíma- } \\
\text { modellezés - a RegCM4.5 regionális } \\
\text { klímamodell alkalmazása }\end{array}$ \\
\hline
\end{tabular}

5. táblázat: A Természettudományi Kar kiváló hallgatói és a Nemzeti Felsőoktatási Ösztöndíjas hallgatóink, 2016-2018.

\begin{tabular}{|l|l|l|}
\hline \multicolumn{1}{|c|}{$\mathbf{E} \mathbf{v}$} & Kar kiváló hallgatója & Nemzeti Felsőoktatási ösztöndíj \\
\hline 2016 & Dian Csenge & Dian Csenge \\
\hline & Farkas Rita & Farkas Rita \\
\hline & Fricke Cathy & Fricke Cathy \\
\hline & Szabó Amanda Imola & Szabó Amanda Imola \\
\hline 2017 & Tímár Ágnes & Sürge Evelin \\
\hline 2018 & Virág Szabolcsné & Incze Dóra \\
\hline \multirow{2}{*}{${ }^{*}$ A kari rangsor alapján valószinüsithetö, még nincs döntés. }
\end{tabular}

2018-ban az Eötvös-napi TDK rendezvényen Virág Szabolcsné vehette át a Kar Kiváló Hallgatója elismerést a Dékán Úrtól. Természetesen ő is készített már TDK dolgozatot. Gratulálunk!

\section{Összefoglaló megjegyzések}

A cikkben az egyetemi rangsorok elemzésétől eljutottunk a meteorológiai kutatás bemutatásán át a diákköri munka fontosságáig. A különböző rangsorokban szereplő hazai egyetemek a 400-1000. közötti helyen vannak. Az egyetemek helyzete a rangsorokban stabilizálódni látszik. Látványos előrejutásra - a velünk együtt induló egyetemek helyzetét is figyelembe véve - nincs lehetőség. Fontos a régióbeli helyzetünk megtartása! Fokozatos előrelépéshez jelentős erőforrások kellenek. Vigyázni kell, nehogy olyan hangzatos célokat tüzzünk ki, amit nem tudunk teljesíteni!

Az ELTE-n folyó légkörtudományi (Atmospheric Science) oktatás és kutatás felkerült a „térképre”. Ebben a meteorológusok mellett a légkörtudományokkal (dinamikai rendszerek, elméleti klímamodellezés) foglalkozó fizikus kollégáknak, illetve a numerikus módszerfejlesztésben publikáló matematikusoknak és a levegőkémiával foglalkozó vegyész kollégáknak is nagy szerepe van. A 2018-as Shanghai listán a 301-400. helyen vagyunk. Ez örömteli! A régiónkból ebben a kategóriában van a Zágrábi és a Belgrádi Egyetem, míg a prágai Károly Egyetem, a brnoi Masaryk Egyetem, a Ljubljanai Egyetem és a krakkói Jagelló Egyetem előrébb foglal helyet (201-300.). A legelőkelőbb hely (51-75.) az Innsbrucki Egyetemé. A Bécsi Egyetem a 101-150. helyen áll. Itt az elsődleges cél a pozíciónk megtartása. Ehhez is további erőfeszítések, erőforrások kellenek. 
A hazai meteorológiai kutatást a szakterületet reprezentáló MTA Meteorológiai Tudományos Bizottság (MTB) kor, munkahely/tevékenység és a bizottsági tagok MTMT-beni publikációs tevékenysége alapján jellemeztük. A kutatás az egyetemi szférába tevődött át. Ott dolgozik a 86 bizottsági tag több mint $40 \%$-a. Ez a tudományos potenciál alkalmassá teszi az egyetemeket alkalmazott kutatási és innovációs feladatok elvégzésére is, természetesen úgy, hogy az eredmények mellett rangos publikációknak is születniük kell. Ehhez bevételekre és erőforrásokra, a fiatal kutatók alkalmazására és megtartására van szükség. (Persze ezt könnyü leírni, s nehéz megvalósitani.)

Az MTA MTB-hez tartozó kutatók korfája közel egyenletes eloszlást mutat. A legfiatalabb bizottsági tag is 30 év feletti. (Belépés csak tudományos fokozattal!) A kutatási témák között a levegökémia és a klimatológia a meghatározó. Az egyetemi és az akadémiai szférában a tudományos megítélés döntő része a publikációs tevékenység és a hivatkozási lista. 12 itthon dolgozó kutatónak van 1000 feletti független hivatkozása, ami a meteorológiában már soknak számít. Közülük négyen a Pannon Egyetemen dolgoznak, az MTA Levegőkémiai Kutatócsoport tagjai. (Kiemelkedö eredmény!) Az OMSZ-ból nemrég nyugdíjba ment két levegökémiával foglalkozó szakember, három éghajlatkutató (ketten Szegedről egy Egerből) tartozik még ebbe a „társaságba”. Az ELTE Meteorológiai Tanszékről ketten vagyunk, s további két 40-50 év közötti kollégának van már 900 feletti hivatkozása. Nem áll rosszul a Tanszék.

Hagyományosan hangsúlyt helyezünk a diákokkal való foglalkozásra, a TDK tevékenységre. Ez az első lépés a kutatóvá váláshoz. A hallgatói létszám csökkenésével a diákköri dolgozatok száma is kevesebb lett, évente 8-10 között alakul. Közös érdekünk és felelösségünk (mármint az oktatóknak és a hallgatóknak), hogy ez a szám ne csökkenjen.

Hallgatóink - számarányukhoz viszonyítva is - jól szerepelnek az OTDK és OFKD konferenciákon. A meteorológia mellett a határtudományokkal foglalkozó szekciókból is hoznak el díjakat. Minden évben ott vannak a Kar kiváló hallgatói és a Nemzeti Felsőoktatási Ösztöndíjasok között. Köszönet érte!

A hagyományos utak, tehetséggondozási formák mellett egyre nagyobb figyelmet kell fordítani az új pályázati lehetőségekre, mint az Új Nemzeti Kiválósági Program (elte.hu/unkp), vagy az ERASMUS+ (elte.hu/erasmus), de ez már a közeli jövő feladata.

\section{Köszönetnyilvánítás}

A szerző köszönetet mond az OTKA K116788, valamint a GINOP-2-3-2-15-2016-00055 és a GINOP 2.3.2.-15-2016-00007 program, továbbá a TÉT_161-20160034 Magyar-Horvát együttműködés támogatásáért, ami lehetőséget teremt korszerü diákköri témák kiírásához.

\section{Hivatkozások}

Bartholy, J., Gyuró, Gy., 2012: A meteorológia oktatásának és kutatásának története az ELTE-n és jogelödjein. Légkör, 57/3: 92-100.

Braun, T., 2010: Egyetemek a világrangsorok büvöletében. Magyar Tudomány, 2010/7: $817-827$.

Csomós Gy., 2014: A nemzetközi egyetemi rangsorok és a Magyar egyetemek publikációs teljesítményének összefüggései: kritikus tényezők és lehetséges megoldásuk. Társadalomkutatás, 32(4), 355-372. https://doi.org/10.1556/Tarskut.32.2014.4.5

Kölcsei, F., 1837: A Magyaróvári Gazdasági Intézet rövid ismertetése. Kölcsey Ferenc összes müvei. 1. kötet, Budapest 1960, Szépirodalmi Könyvkiadó. 1199-1209.

Mester, Gy., 2018: Egyetemi világranglisták 2017. Bánki Közlemények, 1(1): 89-92.

Weidinger, T., 2012: Tehetséggondozás - tudományos diákköri tevékenység az ELTE Meteorológiai Tanszékén. Légkör, 57/3: 111-118. 
Weidinger, T., 2014: A hallgatók részvétele a kutatómunkában itthon és külföldön. In: Légköri folyamatok előrejelzésének módszerei és alkalmazásai. A Meteorológus TDK 2014. évi nyári iskola előadásainak összefoglalói. Egyetemi Meteorológiai Füzetek, 25, (Szerk.: Pongrácz R., Mészáros R., Kis A., Leelössy Á., Sábitz J.), Budapest, 9-21.

Weidinger T., 2016: A Meteorológus TDK: az elmúlt évek eredményei, és ami előttünk van. In: Kutatási és operatív feladatok meteorológusként. Az ELTE Meteorológus TDK Nyári Iskolája. 2016. augusztus 23-25. Hercegkút. Az elöadások összefoglalói. Egyetemi Meteorológiai Füzetek, 27, (Szerk.: Pongrácz R., Mészáros R., Kis A.), Budapest, 9-19.

\section{Internetes hivatkozások:}

- A Magyaróvári Gazdasági Intézet rövid ismertetése (Kölcsei Ferenc, 1837) - mek.oszk.hu/00000/00058/html/kolcsey.htm

- Academic Ranking of World Universities - shanghairanking.com

- CWTS (Centrum voor Wetenschap en Technologische Studies) - leidenranking.com

- Egyetemi rangsorok a társadalomtudomány és bölcsészet kritikai nézőpontjából -ranking.elte.hu/

- Egyetemi rangsorok összehasonlító oldala - universityrankings.ch

- ERASMUS+, ELTE - elte.hu/erasmus

- Magyar Tudományos Akadémia Meteorológiai Tudományos Bizottsága, MTA MTB - mtb.met.hu

- KSH statisztikai táblázatok: 2.6.11. Felsőfokú oktatás (1990-) - ksh.hu/docs/hun/xstadat/xstadat_eves/i_zoi007a.html

- Magyar Tudományos Müvek Tára (MTMT) - mtmt.hu

- Quacquarelli Symonds (QS) (is a British company specialising in education) - qs.com

- The World University Rankings - timeshighereducation.com

- Új Nemzeti Kiválósági Program - elte.hu/unkp

\section{ORCID}

Weidinger T. (D) https://orcid.org/0000-0001-7500-6579 